\title{
The Effect Of Water System (Water Sources, Physical Quality, Chemical, Bacteriological, Quantity And Potential) On Clean Water Availability In Flood And Mining In Banjar District
}

Lenie Marlinae ${ }^{1}$, Danang Biyatmoko ${ }^{2}$, Husaini $^{3}$, Chairul Irawan $^{2}$, Laily khairiyati ${ }^{1}$, Agung Waskito ${ }^{1}$, Akhmad Rizalli Saidy $^{2}$, Abdi Fithria ${ }^{2}$, Anugrah Nur Rahmat ${ }^{1}$, Tien Zubaidah ${ }^{4}$, Syamsul Arifin ${ }^{5}$,Winda Saukina Syarifatul Jannah1, Taufik ${ }^{1}$, Raudatul Jinan ${ }^{1}$

\author{
${ }^{1}$ Public Health Study Program, Faculty of Medicine, Lambung Mangkurat University \\ ${ }^{2}$ Master's Program in Natural Resources and Environmental Management Prog. Postgraduate Lambung Mangkurat University \\ ${ }^{3}$ Master Program in Public Health Sciences, Faculty of Medicine, Lambung Mangkurat University \\ ${ }^{4}$ Banjarbaru Health Polytechnic \\ ${ }^{5}$ Master Program in Public Health Sciences, Faculty of Medicine, Lambung Mangkurat University
}

DOI: 10.29322/IJSRP.11.11.2021.p11934

http://dx.doi.org/10.29322/IJSRP.11.11.2021.p11934

\begin{abstract}
Based on data from the Regional Disaster Management Agency (BPBD) of South Kalimantan Province (2018), the total disaster incidence in the South Kalimantan Region in 2017 was 381 disaster events. There were 54 flood disasters and in 2020 there were 6,670 houses affected and 11,269 people displaced and lack of clean water in Banjar Regency. Based on the 2018 Basic Health Research (Riskesdas) it was shown that in Banjar Regency the use of clean water per person per day was $2.41 \%$. And the comparison of the use of clean water that is less due to the lack of clean water sources between urban $1.90 \%$ and rural $2.50 \%$ is approximately only $0.6 \%$ different. The purpose of this study was to analyze the effect of water management on the availability of clean water in flood-prone areas and mining. Descriptive quantitative research to analyze water management. The result of this research is the source of river water and dug well water. The results of measuring the physical and chemical quality of water in Sungai Alat Village and Kelampapan Ulu Village have pH, TDS, conductivity, turbidity and temperature values at standard values while the Do value is not up to standard, while Keliukan Village has $\mathrm{pH}$, TDS, conductivity, tubidity, Do values. and the temperature is in accordance with the standard. The results of the chemical measurements of both dug wells and rivers do not meet the requirements, namely the MPN Fecal Coliform index in 100 $\mathrm{ml}$ of the sample, which is 1092.2. The quantity of water is sufficient but in a state of an average depth of $75 \mathrm{~m}$ and the quantity and quality is cloudy and the potential is sufficient.
\end{abstract}

Index Terms- water management, flood, mining, astambul

\section{INTRODUCTION}

$\mathrm{D}$ isaster is a phenomenon resulting from changes in ecosystems that occur suddenly in a relatively short time in the relationship between humans and their environment that occur in such a way, such as earthquakes, floods, volcanoes that require immediate countermeasures. Banjar Regency BNPB data shows that flood events occurred 38 times during 2018-2021 with an average flood height of $89.4 \mathrm{~cm}$ (BNPB, 2021). The impact of the floods felt during the floods in South Kalimantan in 2021, namely the closure of rice fields of around 36 hectares, 5 people lost their lives, 27,111 houses were flooded, and 112,709 people evacuated (BNPB, 2021).

Based on the 2018 Basic Health Research (Riskesdas) it was shown that in Banjar Regency the use of clean water per person per day was $2.41 \%$. And the comparison of the use of clean water that is less due to the lack of clean water sources between urban $1.90 \%$ and rural $2.50 \%$ is approximately only $0.6 \%$ different. The lack of clean water sources to fulfill sanitation needs in daily life and the lack of knowledge in how to use water properly in preventing the transmission of covid 19 have an impact on increasing diarrhea cases, namely number 2 (two) as many as 3,317 with the highest prevalence number 1 being in toddlers as much as 280 and child deaths due to COVID-19 cases as many as 121 cases with a CFR of 8.4 in South Kalimantan in 2020 (Riskesdas, 2018, South Kalimantan epidemiological data, 2020).

Technological developments can help overcome various problems related to water as a basic need of life, one of which is by mapping and interpreting the existence of clean springs based on seasons through predictions of their existence associated with land conditions (soil conditions, land color, thickness of organic matter, land cover). Water system (water sources, physical quality, chemical, bacteriological, water discharge, water quantity and potential). From this data, it is hoped that later it can provide a real picture to meet the needs of the community, especially in waterpoor areas, flood-prone areas and mining. Based on this background, researchers are interested in conducting research on land conditions (soil conditions, land color, thickness of organic matter, land cover), water system (water sources, physical quality, chemistry, bacteriological, water discharge, water quantity and potential) so that problems can be identified in efforts to manage clean water which will be applied in community empowerment activities later in flood and mining prone areas in Banjar Regency. 


\section{METHOD}

This research is a descriptive quantitative research to analyze the water system. The instruments that will be used in this research are fill sheets, physical, chemical and bacteriological water measuring instruments through laboratory tests, current water tools to measure water discharge.

\section{Physical and Chemical Measurement of Water}

\section{RESULTS}

Table 1. Physical, chemical, bacteriological measurements of water

\begin{tabular}{|c|c|c|c|c|}
\hline No & village & Measurement Type & Score & Information \\
\hline \multirow{4}{*}{1} & $\mathrm{pH}$ & $258 \mathrm{mg} / \mathrm{L}$ & Standard \\
\cline { 3 - 5 } & \multirow{4}{*}{ Kelampaian Ulu } & TDS & 1229 & Standard \\
\cline { 3 - 5 } & & Conductivity & $366 \mathrm{NTU}$ & Not Up to Standard \\
\cline { 3 - 5 } & & Turbidity & $6.4 \mathrm{mg} / \mathrm{L}$ & Standard \\
\cline { 3 - 5 } & & Do & $31.4 \mathrm{C}$ & Standard \\
\cline { 3 - 5 } & & Temperature & $258 \mathrm{mg} / \mathrm{L}$ & Standard \\
\cline { 3 - 5 } & & MPN Coliform & $>1600 \mathrm{ml}$ & Not Up to Standard \\
\hline
\end{tabular}

Description of Quality Standards:

$\begin{array}{lll}\text { a. } & \mathrm{pH} & : 6.5-8.5 \\ \text { b. } & \text { TDS } & : 1-500 \\ \text { c. } & \text { Conductivity } & : 1-200 \\ \text { d. } & \text { Turbidity } & : 25 \\ \text { e. } & \text { Do } & :>4 \mathrm{Mg} / \mathrm{L} \\ \text { f. } & \text { Temperature } & : 30-36 \mathrm{C} \\ \text { g. } & \text { MPN Coliform } & : 100 \mathrm{ml}\end{array}$

a. When measuring $\mathbf{p H}$, it expresses the intensity of the acidity or alkalinity of a dilute liquid, and represents the hydrogen ion concentration. $\mathrm{pH}$ is an important parameter in water quality analysis because of its influence on biological and chemical processes in it. The results of the physical quality examination, namely the acidity $(\mathrm{pH})$ of water which is smaller than 6.5 or acidic $\mathrm{pH}$ increases the corrosiveness of metal objects, causes an unpleasant taste and can cause some chemicals to become toxic that interfere with health. The test results of well water samples before treatment at the Keliuakan location were in accordance with the standard with a value of $\mathrm{pH} 8.27$ So it can be concluded that all samples of dug well water from TDS parameters are in accordance with the standards set by government regulation No. 82 of 2001 concerning water quality management and water pollution control.

b. Measurement of Total Dissolved Solid (TDS) is a term to indicate the amount of dissolved solids or the concentration of the number of cations (positive charge) and anions (negative charge) in the water. TDS is described by the amount of solute in Parts Per Million (PPM) or equal to milligrams per Liter $(\mathrm{mg} / \mathrm{L})$. The results of the physical quality inspection, namely the amount of dissolved substances (TDS) in dug well water in the village of Keliukan according to the standard with a value of $339 \mathrm{mg} / \mathrm{L}$. So it can be concluded that all samples of dug well water from the TDS parameter according to the standards set by PerMenKes 907/Menkes/SK/VII/2002 are $500 \mathrm{mg} / \mathrm{L}$

c. The results of the physical quality inspection are for the measurement of conductivity in dug well water in the sungai alat village of $734 \mu$, for the Kelampapan Ulu village of $1262 \mu$, and for the twisted village it is $1620 \mu$ . So it can be concluded that all samples of dug well water that are examined for the value of water conductivity can be stated to have not reached the threshold in $\mathrm{mhos} / \mathrm{cm}$ or Siemens/cm units. Shallow groundwater generally has a price of 30-2000 $\mu \mathrm{mhos} / \mathrm{cm}$.

d. Turbidity measurements indicate the presence of particles from the soil and the possibility of contamination of metals such as iron, manganese, and so on. The results of the physical quality inspection, namely the level of turbidity in dug well water, the results of testing well water samples at the Keliuakan location, obtained turbidity according to the standard with a value of 6.08 NTU. So it can be concluded that all of the dug well water samples that were examined for the value of the turbidity level did not exceed the threshold set by Minister of Health Regulation 907/Menkes/SK/VII/2002 is $25 \mathrm{NTU}$.

e. Dissolved oxygen or DO (Dissolved oxygen)is the amount of dissolved oxygen in water that comes from photosynthesis and absorption of the atmosphere/air. 
Dissolved oxygen in water plays a very important role in the process of absorption of food by living things in the water. To know the quality of water in a waters, it can be done by observing several chemical parameters such as dissolved oxygen (DO). The more DO (Dissolved oxygen) amount, the better the water quality if the dissolved oxygen level is too low it will cause unpleasant odor due to anaerobic degradation that may occur. The results of the physical quality examination, namely the level of Dissolve Oxygen (DO) in dug well water The test results of well water samples at Sungai Alat obtained Dissolve Oxygen (DO) according to the standard with a value of $1.4 \mathrm{mg} / \mathrm{L}$ at the Dissolve Oxygen (DO) location obtained according to the standard with a value of 5.3 $\mathrm{mg} / \mathrm{L}$. So it can be concluded that the area for the village of Keliukan passed the threshold set by Government Regulation No. 82 of 2001 which is more than 4.

f. TemperatureThe air in the three villages at the time of sampling was $33^{\circ} \mathrm{C}$, so the standard temperature values ranged from $30-36^{\circ} \mathrm{C}$. The results of the physical quality inspection, namely the temperature level in dug well water, the results of testing well water samples at the
Keliuakan location, obtained the temperature according to the standard with a value of 35.9 celsius. So it can be concluded that all of the dug well water samples examined for the value of the turbidity level did not exceed the threshold set by Minister of Health Regulation 907/Menkes/SK/VII/2002, which is 30-36 Celsius.

\section{Results of Geoelectrical Measurements in Kaliukan Village, Astambul District}

A geoelectric investigation of the resistivity method has been carried out using the OYO McOHM 2119EL brand Resistivitimeter made in Japan on September 26, 2021 with a Shclumberger configuration of 6 ( six) measurement points. The coordinates of the measurement location are GL-2 (Kaliukan Village) with - 03o 21'39.34" and 114o 49' 45.62"

This activity is intended to investigate the distribution and arrangement of subsurface lithology based on the nature of the rock type resistance. The aim is to find out the possibility of a layer of soil/rock that functions as a water trap (aquifer) which can then be used as a basis for planning the development of underground water by drilling.

\section{E-1 10E0 10E1 10E2 10E3 10E4 10E5 10E6}

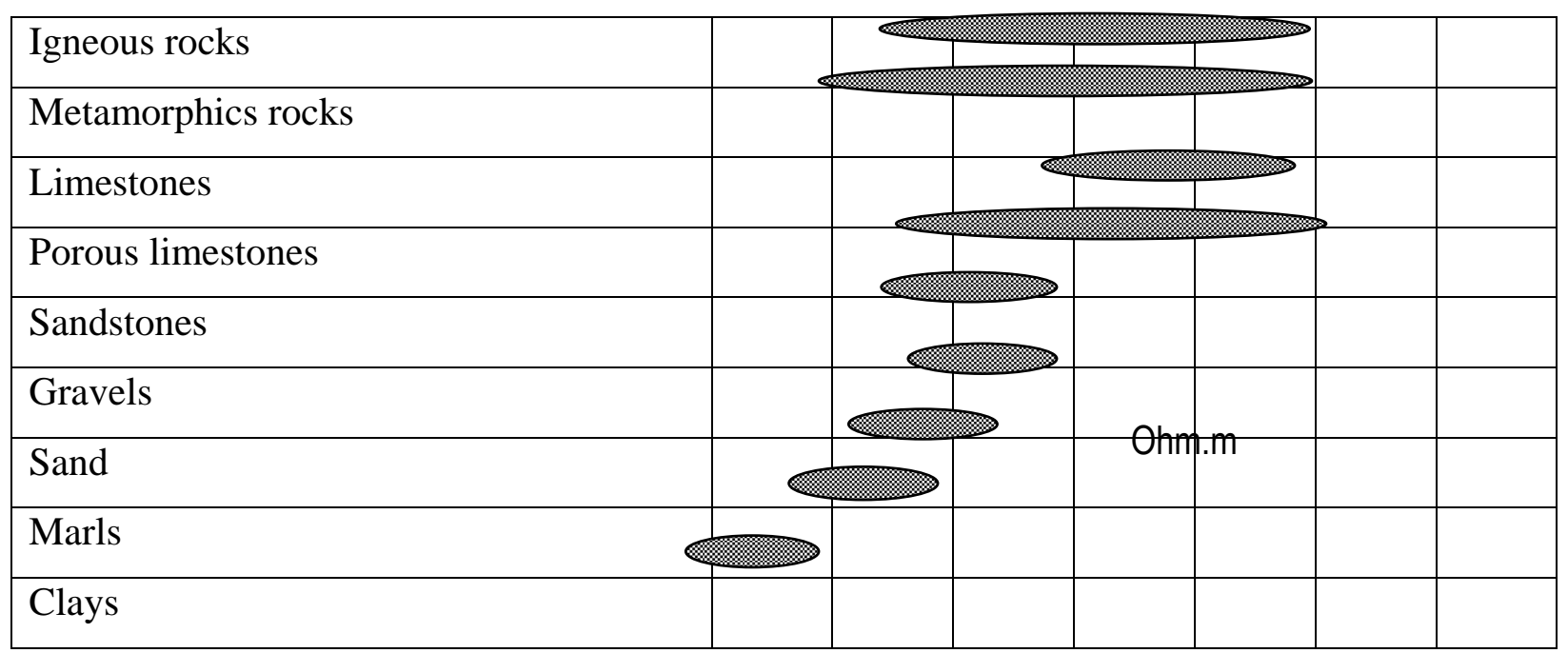

Value relationship between rock type resistance

Based on the results of the interpretation of the geoelectrical estimation with the help of a computer and it has been correlated with local geological and hydrogeological data, the resistivity log is obtained at each estimation point as shown in the following table below:

\begin{tabular}{|c|c|c|c|c|c|c|c|}
\hline \multirow[b]{2}{*}{$\begin{array}{l}\text { Point } \\
\text { guess }\end{array}$} & \multirow[b]{2}{*}{ Layer } & \multicolumn{3}{|c|}{ Interpretation results } & \multirow[b]{2}{*}{$\begin{array}{c}\text { Estimation } \\
\text { lithology }\end{array}$} & \multirow[b]{2}{*}{$\begin{array}{l}\text { Attitude of rocks } \\
\text { to groundwater }\end{array}$} & \multirow[b]{2}{*}{ Water quality } \\
\hline & & Depth (m) & $\begin{array}{c}\text { Thick } \\
\text { (m) }\end{array}$ & $\begin{array}{c}\text { Specific } \\
\text { Resistance } \\
(\Omega \mathrm{m})\end{array}$ & & & \\
\hline GL2 & $\begin{array}{l}1 \\
2 \\
3 \\
4 \\
5\end{array}$ & $\begin{array}{c}0.0-1.09 \\
1.09-15.95 \\
15.95-29.49 \\
29.49-73.99 \\
73.99--\end{array}$ & $\begin{array}{c}1.09 \\
14.86 \\
13.54 \\
44.50 \\
\square\end{array}$ & $\begin{array}{c}48.23 \\
8.62 \\
40.69 \\
2.91 \\
133.53\end{array}$ & $\begin{array}{c}\text { Cover ground } \\
\text { Clay } \\
\text { Sand } \\
\text { Clay } \\
\text { Sand }\end{array}$ & $\begin{array}{l}\text { Wet } \\
\text { aquiclud } \\
\text { aquifer } \\
\text { aquiclud } \\
\text { aquifer }\end{array}$ & cloudy \\
\hline
\end{tabular}


The value of resistivity at the investigation site can be divided into several groups, namely:

a. resistivity $0.33-1.21 \mathrm{~m}$ at the top at a depth of $0.0-2.00$ meters is interpreted as overburden and rock that is wet,

b. Specific resistance $<10 \Omega \mathrm{m}$, interpreted as clay that is impermeable to water (aqueous),

c. The resistivity is $10-30 \Omega \mathrm{m}$, interpreted as a sandy clay with poor aquifer characteristics,

d. The resistivity of $30-150 \Omega \mathrm{m}$ is interpreted as sand with poor aquifer characteristics,

e. Specific resistance of $150-300 \Omega \mathrm{m}$, interpreted as good aquifer sand.

The results obtained are: At the GL-2 measurement location it is recommended to drill a sand layer with a depth of $>75 \mathrm{~m}$, the lithological layer that is targeted is a type of sand with a resistivity of $133.53 \mathrm{~m}$ which is a good water-passing aquifer (aquifer). and groundwater quality looks cloudy.

\section{DISCUSSION}

\section{Physical, chemical and bacteriological measurements of water}

Total Dissolved Solid (TDS) or dissolved solids are solids that have a smaller size than suspended solids. Dissolved materials in natural waters are not toxic, but if they are excessive they can increase the turbidity value which will further inhibit the penetration of sunlight into the water and ultimately affect the photosynthesis process in the waters. High levels of TDS if not managed and processed can pollute water bodies. In addition, it can kill aquatic life, and has adverse side effects on human health because it contains high concentrations of chemicals, including phosphate, surfactant, ammonia, and nitrogen as well as high levels of suspended and dissolved solids, turbidity, BOD5, and COD. high (Kustiyaningsih E and Irawanto R, 2020). The content of TDS in water can also give a taste to water, namely water becomes like salt, so that if water containing TDS is drunk, there will be an accumulation of salt in the human kidneys, so that over time it will affect the physiological function of the kidneys (Afrianita, et al, 2017).

The high TDS content in water can be overcome by the reverse osmosis method, which is a method in which the water will be distilled to separate the water from the substances contained in it. Treatment of brackish water with reverse osmosis system consists of two parts, namely the initial treatment unit (Pretreatment) and the advanced treatment unit (Treatment), namely the reverse osmosis unit. The preliminary treatment unit consists of several main equipment, namely a raw water pump, a dosing pump equipped with a chemical tank, a reactor tank (contactor), a sand filter, a zeolite manganese filter, and a filter for color removal/activated carbon filter, and filter cartridge size 0.5 $\mu \mathrm{m}$. While the advanced processing unit consists of a high pressure pump, reverse osmosis membrane, a dosing pump for anti-scalding (antiscalant) and anti-fungal (anti-biofoaling) materials equipped with a chemical tank and an ultra violet (UV) sterilizer (Sulaeman O, 2020).

A slight change in $\mathrm{pH}$ from the natural $\mathrm{pH}$ will give an indication of a disturbed buffer system. This can cause changes and imbalances in $\mathrm{CO} 2$ levels that can endanger the life of biota in the water. High and low $\mathrm{pH}$ is influenced by fluctuations in the content of $\mathrm{O} 2$ and $\mathrm{CO} 2$. Not all creatures can withstand changes in $\mathrm{pH}$ values, for that nature has provided a unique mechanism so that changes do not occur or occur but slowly. A pH level less than 4.8 and greater than 9.2 can be considered polluted (Rukminasari $\mathrm{N}$, et al, 2014).

The $\mathrm{pH}$ value can affect the toxicity of a chemical compound, the higher the $\mathrm{pH}$ value, the higher the alkalinity value and the lower the carbon dioxide level. If the $\mathrm{pH}$ is low, then the water is acidic and corrosive, metal toxicity will increase, and the nitrification process will be hampered. The high level of $\mathrm{pH}$ in the water causes the water to become acidic which results in disruption of the life of organisms in the water, including organisms that undergo a calcification process in their life cycle, such as Halimeda sp. Halimeda sp is a type of macroalgae that contains calcium levels, where in its life cycle there is a calcification process that is able to drown $\mathrm{CO} 2$ in waters (Rukminasari N, et al, 2014).

If the $\mathrm{pH}$ value in the water is not normal, several ways can be done to be able to normalize the $\mathrm{pH}$ value again. For $\mathrm{pH}$ below 6.5 or acidic, it can be overcome in a natural way, namely by providing a filter consisting of coral fragments and shell fragments mixed with pieces of limestone in the pond aeration channel. If the pool water is alkaline or the $\mathrm{pH}$ value is high, then you can use ketapang leaves to lower it. The trick is to soak the ketapang leaves in the bottom of the water for a few days. Before soaking the ketapang leaves, first boil the ketapang leaves to remove the tannins contained, because the tannins can cause a yellow color in the water (Ariyani $\mathrm{S}$, et al).

Measurement of Conductivity (Electrical Conductivity/DHL) is a numerical description of the ability of water to carry electricity. Therefore, the more dissolved salts that can be ionized, the higher the DHL value. Measurement of electrical conductivity aims to measure the ability of ions in water to conduct electricity and predict mineral content in water. The higher the conductivity content in the water, the more dangerous it is because it can precipitate and damage kidney stones. According to WHO, the threshold value for the conductivity / electrical conductivity of drinking water sources is $1500 \mu \mathrm{S} / \mathrm{cm}$ (Nurhidayati et al, 2021).

The high and low conductivity values in coastal well water can be influenced by the large mass of seawater that pollutes groundwater. Electrolyte content includes salts dissolved in water, related to the ability of water to conduct electric current. The more dissolved salts the better the electrical conductivity of the water. High conductivity values cause water to easily conduct electricity and indicate the presence of a high salt content. The high salt content in peat water will cause the water to have a salty taste so it is not suitable for consumption. In addition, the impact of high water conductivity values will lead to low diversity of aquatic animals (Said et al, 2019).

Research on sodium ions that can be exchanged for hydrogen ions derived from cation exchange resins with a batch system has been carried out by Aulia (2002). In Partuti's research, an ion exchange process was carried out using a cation exchange resin to reduce the concentration of TDS in the waste water produced by a column system, so that the output water from the cation exchange process was safely discharged into the environment in accordance with the established quality standards. Research on reducing the concentration of TDS and conductivity in the reactor primary 
cooling water using ion exchange resin has also been carried out by Lestari, et al (2006). The replacement of ion exchange resin after saturation will greatly affect the quality of the primary cooling water for the better, where the conductivity of the water becomes smaller, The $\mathrm{pH}$ of the water is close to pure water and the TDS concentration is lower than the maximum limit specified. Maulana and Widodo studied the variation in the ratio of cation and anion resin to decrease in TDS concentration and conductivity, where the ratio of 4:6 cation and anion resin resulted in low product water conductivity (Partuti T, 2014).

Turbid water conditions are caused by changes in the ecosystem in natural water sources and poor local water conditions so that the water quality decreases and is not suitable for domestic use, especially for drinking water. The presence of organism activity in the form of bacteria in the well is one of the factors that the well smells. In addition, turbidity in water is caused by the presence of suspended solids such as clay, organic matter, plankton and other fine substances. Turbid and dirty water is the cause of infectious diseases such as: Typus abdominalis, Cholera, diarrhea, and dysentery biciller. Although disease-causing bacteria can be killed by boiling water, there are also harmful substances, especially metals that can cause poisoning (Adeko et al, 2019).

There are various simple ways that we can use to get clean water, and the easiest and most commonly used way is to make a water filter, and for us perhaps the most appropriate is to make a water purifier or a simple water filter. It should be noted that the clean water produced from this simple water filtration process cannot completely remove the dissolved salts in the water. Use simple distillation to produce salt-free water. Slow Sand Filter (SPL) aka Slow Sand Filter (SSF) has long been known in Europe since the early 1800s. To meet the need for clean water, the Slow Sand Filter can be used to filter cloudy water or dirty water. The Slow Sand Filter is very suitable to meet the need for clean water in small-scale communities or household scales. This is none other than because the clean water discharge produced by SPL is relatively small. The filtering process on the Slow Sand Sieve is carried out physically and biologically. Physically, the particles in a cloudy or dirty water source will be retained by a layer of sand in the filter. Biologically, the filter will form a layer of bacteria. Bacteria from the genera Pseudomonas and Trichoderma will grow and reproduce to form a special layer. During the filtration process with slow water flow (100-200 liters/hour/m2 filter surface area), the pathogens retained by the filter will be destroyed by these bacteria (Wibowo S, 2013).

Dissolved oxygen (OT) indicates the distribution of oxygen in water bodies which is used as a basis for assessing water quality conditions. The DO value fluctuates depending on organic pollutants (BOD) and the natural purification of the river. Concentrations of pollutants discharged into rivers can reduce DO content due to consumption by microbes to degrade organic matter (deoxygenation). On the other hand, the condition of the hydraulic profile of the river that forms a certain relief causes oxygen supply from the atmosphere due to turbulence in the water flow so that the DO content in river waters increases (reoxygenation). The rate of reduction of dissolved oxygen is expressed in the rate of deoxygenation (rD) and the rate of addition of dissolved oxygen in the waters is expressed by the rate of reoxygenation (rR) (Novita et al, 2021).

This publication is licensed under Creative Commons Attribution CC BY.

http://dx.doi.org/10.29322/IJSRP.11.11.2021.p11934
The more plants found in the river will increase the dissolved oxygen level in the river, so that if the river is given plants, the dissolved oxygen level is still higher than a river that has no plants at all, because plants release oxygen through the process of photosynthesis. In addition to photosynthesis, aeration in rivers has also been shown to increase dissolved oxygen levels in rivers (Priyantini HR et al, 2001).

The measurement of the temperature of clean water should not be hot, because the hot temperature can help dissolve the chemicals present in the water channels/pipes and water containers (Sudibyo, 1999). According to the Regulation of the Minister of Health of the Republic of Indonesia No. 416/MENKES/PER/IX/1990, the standard temperature for clean water is: air temperature \pm 3 Celsius. The solubility of oxygen in high-temperature water is relatively small, so it can harm the life of microbes or living things in the water (Dahruji et al, 2017).

\section{Results of Geoelectrical Measurements in Kaliukan Village, Astambul District}

This activity is intended to investigate the distribution and arrangement of subsurface lithology based on the nature of the rock type resistance. The aim is to find out the possibility of a layer of soil/rock that functions as a water trap (aquifer) which can then be used as a basis for planning the development of underground water by drilling.

The value of resistivity at the investigation site can be divided into several groups, namely:

a. Resistivity $0.33-1.21 \mathrm{~m}$ at the top at a depth of $0.0-$ 2.00 meters is interpreted as overburden and rock that is wet,

b. Specific resistance $<10 \mathrm{~m}$, interpreted as clay that is impermeable to water (aqueous),

c. The resistivity is $10-30 \mathrm{~m}$, interpreted as a sandy clay with poor aquifer characteristics,

d. The resistivity of $30-150 \mathrm{~m}$ is interpreted as sand with poor aquifer characteristics,

e. Specific resistance of $150-300 \mathrm{~m}$, interpreted as sand with good aquifer properties.

At the GL-2 measurement location, it is recommended to drill a layer of sand with a depth of $>\mathbf{7 5} \mathbf{~ m}$, the lithological layer that is targeted is a type of sand with a resistivity of $\mathbf{1 3 3 . 5 3} \mathbf{\Omega m}$ which is an aquifer that is good in quantity and quality of groundwater seen cloudy.

\section{CONCLUSIONS}

\section{Conclusion}

Conclusions obtained from this study:

a. The results of physical and chemical measurements in Keliukan Village have $\mathrm{pH}$, TDS, conductivity, turbidity, Do and temperature values according to the standard

b. Microbiological measurement results exceed the standard

c. The result of measuring the depth of the water source is $75 \mathrm{~m}$ and the quantity and quality is cloudy

\section{Suggestion}

There needs to be cooperation with all parties, especially the Banjar Regency Environmental Service regarding improving water quality physically, chemically and bacteriologically to 
improve the quality of water for the availability of clean water in flood-prone areas and mining.

\section{REFERENCES}

[1] Adeko, R., Mualim, M., \& Octafia, M. (2019). PENGARUH SERBUK BIJI KECIPIR SEBAGAI KOAGULAN TERHADAP PENURUNAN KEKERUHAN DALAM AIR SUMUR GALI DI KELURAHAN RAWA MAKMUR. Journal of Nursing and Public Health, 7(2), 51-55.

[2] Afrianita, Reri dkk. 2017. Analisis Intrusi Air Laut dengan Pengukuran Total Dissolved Solid (TDS) Air Sumur Gali di Kecamatan Padang Utara. Jurnal Teknik Lingkungan UNAND

[3] Ariyani S. 2020. Peningkatan kualitas keasaman (ph) pada sumber air untuk industri air mineral dengan metode penyaringan. Jurnal Borneo Akcaya; 6(1): $33-42$.

[4] Dahruji, D., Wilianarti, P. F., \& Hendarto, T. T. (2016). Studi Pengolahan Limbah Usaha Mandiri Rumah Tangga dan Dampak Bagi Kesehatan di Wilayah Kenjeran, Surabaya. Aksiologiya: Jurnal Pengabdian Kepada Masyarakat, 1(1), 36-44.

[5] Novita, E., Anwar, B. R. Y., \& Pradana, H. A. 2021. Evaluasi Kondisi Kualitas Air Berdasarkan Dampak Beban Pencemaran Terhadap Sebaran Oksigen Terlarut Di Sungai Gunung Pasang Kabupaten Jember. Ecotrophic. 15(1): 90-102.

[6] Nurhidayati; DIDIK, Lalu A.; ZOHDI, Ahmad. 2021. Identifikasi Pencemaran Logam Berat di Sekitar Pelabuhan Lembar Menggunakan Analisa Parameter Fisika dan Kimia. Jurnal Fisika Flux: Jurnal Ilmiah Fisika FMIPA Universitas Lambung Mangkurat, 18.2: 139-148.

[7] Partuti, T. (2014). Efektivitas Resin Penukar Kation untuk Menurunkan Kadar Total Dissolved Solid (TDS) dalam Limbah Air Terproduksi Industri Migas. Jurnal Integrasi Proses, 5(1)

[8] Priyantini, H. R., Cicilya, E., \& Surjono, E. (2001). Simulasi Pengaruh Buangan Limbah Organik Terhadap Konsentrasi Oksigen Terlarut Di Sepanjang Aliran Sungai.

[9] Said, Y. M., et al. 2019. Karakteristik Fisika dan Kimia Air Gambut Kabupaten Tanjung Jabung Barat, Provinsi Jambi. Jurnal Sains dan Teknologi Lingkungan, 11.2: 132-142.

[10] Sulaeman O. 2020. Aplikasi teknologi pengolahan air asin menggunakan membran reverse osmosis di pulau Barrang Caddi, Makassar. Jurnal Rekayasa Lingkungan, 13(1): 1-9.

[11] Wibowo, S. (2013). Teknik Penjernihan Air. Makalah. Universitas Negeri Yogyakarta.

\section{AUTHORS}

First Author - Lenie Marlinae, Public Health Study Program, Faculty of Medicine, Lambung Mangkurat University

Second Author - Danang Biyatmoko, Master's Program in Natural Resources and Environmental Management Prog. Postgraduate Lambung Mangkurat University

Third Author - Husaini, Master Program in Public Health Sciences, Faculty of Medicine, Lambung Mangkurat University Fourth Author - Chairul Irawan, Master's Program in Natural Resources and Environmental Management Prog. Postgraduate Lambung Mangkurat University

Fifth Author - Laily khairiyati , Public Health Study Program, Faculty of Medicine, Lambung Mangkurat University

Sixth Author - Agung Waskito , Public Health Study Program, Faculty of Medicine, Lambung Mangkurat University

Seventh Author - Akhmad Rizalli Saidy, Master's Program in Natural Resources and Environmental Management Prog.

Postgraduate Lambung Mangkurat University

Eight Author - Abdi Fithria, Master's Program in Natural Resources and Environmental Management Prog. Postgraduate Lambung Mangkurat University

Nine Author - Anugrah Nur Rahmat, Public Health Study Program, Faculty of Medicine, Lambung Mangkurat University Tenth Author - Tien Zubaidah, Banjarbaru Health Polytechnic Eleventh Author - Syamsul Arifin, Master Program in Public Health Sciences, Faculty of Medicine, Lambung Mangkurat University

Twelfth Author - Winda Saukina Syarifatul Jannah, Public Health Study Program, Faculty of Medicine, Lambung Mangkurat University

Thirteenth Author - Taufik, Public Health Study Program, Faculty of Medicine, Lambung Mangkurat University

Fourteen Author - Raudatul Jinan, Public Health Study Program, Faculty of Medicine, Lambung Mangkurat University 